\title{
Siliceous microalgae in the Holocene sediments of Lake Ladoga
}

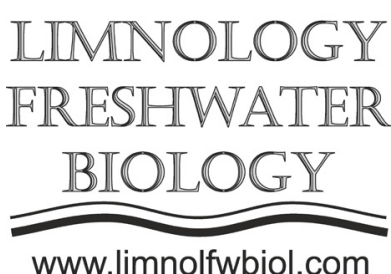

\author{
Ludikova A.V. \\ Institute of Limnology, Russian Academy of Sciences, Sevastyanova str. 9, St. Petersburg 196105, Russia
}

\begin{abstract}
The study of the siliceous microalgae in Lake Ladoga Holocene sediments revealed four main stages of the lake ecosystem evolution. The Early Holocene was the most favourable time for chrysophytes as they gained competitive advantages under the low-nutrients and low-temperature conditions. Parallel fluctuations in diatom and cyst concentrations suggest that their growth is controlled by the same environmental factors. In the second half of the Holocene, restructuring of the microalgal communities took place reflected as a decreased proportion of chrysophyte cysts.
\end{abstract}

Keywords: siliceous microalgae, diatoms, chrysophyte cysts, Lake Ladoga, sediments, Holocene

\section{Introduction}

Lake Ladoga, the largest European lake, contains well-preserved Late Glacial-Holocene sediment records. Diatoms are traditionally used in reconstructing the evolution of Lake Ladoga ecosystem. Chrysophyte cysts (resting stages of the golden algae, Chrysophyceae) is another abundant group of siliceous microfossils in the Ladoga sediments which, however, was not considered in paleoreconstructions till recently. In the present study we introduced the cysts concentrations and cysts to diatoms ratio as an additional characteristics of the lake paleoproductivity and microalgal community structure.

\section{Materials and methods}

The sediment cores were retrieved from the deep-water parts of Lake Ladoga (111 m and $68 \mathrm{~m}$ ) within the Russian-German research project PLOT in 2013 (e.g. Gromig et al., 2019), and during the regular Lake Ladoga expedition of the Institute of Limnology, Russian Academy of Sciences, in 2016 (Sapelko et al., 2019). Chrysophyte cysts were counted alongside with diatoms. The concentrations of the siliceous microalgal remains and cysts to diatoms (CY:DI) ratio were subsequently calculated.

\section{Results and discussion}

The siliceous microalgae stratigraphy revealed the following stages of the evolution of the Ladoga ecosystem in the Holocene. In the Early Holocene, the diatom assemblages are dominated by planktonic
Aulacoseira islandica, the most abundant taxon in Lake Ladoga diatom records since the deglaciation. The presence of the indicative "Ancylus Lake" species (Cymbella sinuata, Diploneis domblittensis, Opephora martyi etc) correlates this stage to the Ancylus Lake stage, the Early Holocene freshwater stage of the Baltic that occupied the major part of the Ladoga basin. Low concentrations of both groups of siliceous microalgae indicate low productivity and higher sedimentation rates. The highest CY:DI values observed at this stage are also typical for the Ancylus Lake sediments retrieved from small lakes in the Ladoga region (e.g. Ludikova et al., 2020). We argue therefore that the Early Holocene environments in Lake Ladoga were the most favourable for chrysophytes. At present, chrysophytes are abundant in Lake Ladoga in summer phytoplankton, however, they are overdominated by the blue-greens, greens, cryptophyceans and diatoms (Letanskaya and Protopopova, 2012). In the Ancylus times, chrysophytes apparently had competitive advantages under the lownutrients and low-temperature conditions. Besides, the specific thermal regime of the large, deep and coldwater Ancylus Lake controlled the start and duration of the water mixing, stratification period etc., which, in turn, influenced the phytoplankton development.

After the termination of the Ancylus Lake stage (ca. 10000 cal. yrs BP) both diatom and cyst concentrations tend to increase, indicating the productivity growth as the climate warmed. The diatom abundances considerably exceed those of chrysophytes reflecting their contributions to the microalgal community. Parallel fluctuations of diatom and cyst concentrations, also observed at the later stages suggest that they are influenced by the same environmental factors. The 
CY:DI ratio remains rather high suggesting that the environments were still favourable for chrysophytes during the climatic optimum of the Holocene. The specifics of these environments are apparently reflected in the diatom assemblages predominated by $A$. islandica with negligible amounts of other species.

The following stage is characterized by rapid increase in diatom concentrations after ca. 4700 cal. yrs BP. Planktonic Aulacoseira subarctica co-dominates in the diatom assemblages, while the proportion of $A$ islandica significantly decreases. It might be somehow related to the mid-Holocene Lake Ladoga transgression, when the large areas of coastal lowlands were inundated thus expanding the littoral zone where the vernal development of diatoms starts. The abundances of cysts demonstrated no changes remaining the same as at the previous stage. The CY:DI ratio decreases almost twofold and later stabilizes at its lowest values starting from ca. 3000 cal. yrs BP until present. Around this time, the Ladoga transgression terminated, the Lake Ladoga basin gained its present configuration and water volume, and the lake ecosystem is thought to have changed accordingly. In the surface sediments of Lake Ladoga, the CY:DI ratio remains very low, which corresponds to the low contribution of chrysophytes to the present-day phytoplankton biomass (Holopanen and Letanskaya, 1999).

\section{Conclusions}

The study of the siliceous microalgae in the Holocene Lake Ladoga sediments revealed four main stages of the ecosystem evolution based on the diatom assemblages composition, diatom and chrysophyte cysts concentrations, and cysts to diatom ratio. We argue that the Early Holocene was the most favourable time for chrysophytes, probably due to the different thermal regime of the lake and their competitive advantages under the low-nutrients and low-temperature conditions. Parallel fluctuations in diatom and cyst concentrations suggest that their development in the phytoplankton is controlled by the same environmental factors. Changing diatom assemblages composition, increasing diatom concentrations and decreased proportion of chrysophytes in the second half of the Holocene indicate restructuring of the microalgal communities.

\section{Acknowledgments}

The study contributes to the State Research Program of the Institute of Limnology, RAS, No 01542019-0001.

\section{References}

Gromig R., Wagner B., Wennrich, V. et al. 2019. Deglaciation history of Lake Ladoga (northwestern Russia) based on varved sediments. Boreas 48: 330-348. https://doi. org/10.1111/bor.12379.

Holopainen A.-L., Letanskaya G. I. 1999. Effects of nutrient load on species composition and productivity of phytoplankton in Lake. Boreal Environmental Research 4: 215-227.

Letanskaya G. I., Protopopova E. V. 2012. The Current State of Phytoplankton in Lake Ladoga (2005-2009) Inland Water Biology 4: 17-24. (In Russian)

Ludikova A.V., Shatalova A.E., Subetto D.A. et al. 2020. Diatom-inferred palaeolimnological changes in a small lake in the context of the Holocene Baltic Sea transgressions: a case study of Lake Goluboye, Karelian Isthmus (NW Russia). IOP Conference Series: Earth and Environmental Science 438. https://doi.org/10.1088/1755-1315/438/1/012014

Sapelko T., Pozdnyakov Sh., Kuznetsov D. et al. 2019. Holocene sedimentation in the central part of Lake Ladoga. Quaternary International 524: 67-75. https://doi. org/10.1016/j.quaint.2019.05.028 